\title{
The Food, Water, Air and Fire Doctrines in Ancient Indian and Greek Philosophies from a Comparative Perspective
}

\author{
Lenart $\check{S} K O F^{*}$
}

\begin{abstract}
The main aim of this article lies in the comparison of ancient cosmico-natural elements from the Vedic period with their counterparts in the Presocratics, with a focus on food, air, water and fire. By way of an introduction to the ancient elemental world, we first present the concept of food (anna) as an idiosyncratic Vedic teaching of the ancient elements. This is followed by our first comparison-of Raikva's natural philosophy of Vàyu/ prāna with Anaximenes's pneûma/aér teaching in the broader context of both the Vedic and Presocratic teachings on the role of air/breath. Secondly, water as brought to us in pañcāgnividyā teaching from Brhadāranyaka Upanișad and Chāndogya Upanișad is compared to the teaching of the Greek natural philosopher Thales. Finally, the teaching on fire as heat being present in all beings (agni vaiśvānara) and in relation to cosmic teachings on fire in the ancient Vedic world are compared to Heraclitus' philosophy of fire as an element. Additionally, this article also presents a survey and analysis of some of the key representatives of comparative and intercultural philosophy dealing with the elemental and natural philosophy of ancient India and Greece.
\end{abstract}

Keywords: Vedic philosophy, Presocratics, food, air, water, fire, philosophy of nature, comparative philosophy

\section{Doktrine hrane, vode, zraka in ognja v stari indijski in grški filozofiji s kom- parativnega vidika}

\section{Izvleček}

Članek se ukvarja s primerjavo starih kozmično-naravnih elementov iz vedskega obdobja s predsokratskimi elementi: hrano, zrakom, vodo in ognjem. Najprej se v uvodu v starodavni svet elementov ukvarjamo z elementom hrane (anna) kot indijsko posebnostjo v okviru starih učenj o elementih. Temu sledi prvi od treh osrednjih delov članka, $\mathrm{v}$ katerem se posvečamo primerom indijske filozofije narave (Raikva in nauki o Vāyul prāna) ter grškemu nauku filozofa Anaksimenesa o pneûma/aér - oboje v širšem kontekstu starih vedskih in predsokratskih učenj o vlogi zraka/vetra/diha. V drugi osrednji analizi

Lenart ŠKOF, Institute for Philosophical Studies, Science and Research

Centre Koper.

E-mail address: lenart.skof@guest.arnes.si

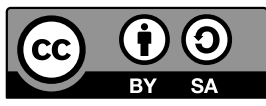


se posvečamo učenju o vodi (pañcāgnividyā) v Brhadāranyaka upanișadi in Chāndogya upanișadi ter sorodnih starih vedskih tekstih in ta nauk primerjamo s starimi grškimi nauki o vodi, ki jih najdemo $\mathrm{v}$ Talesovi filozofiji narave. $V$ sklepnem delu se posvečamo še indijskim vedskim naukom o ognju kot toploti, prisotni v vseh bitjih (agni vaiśvānara), ter spremljajočih kozmičnih učenjih stare Indije. Te nauke primerjamo s filozofijo grškega misleca Heraklita. Poleg tega članek prinaša pregled in analizo najpomembnejših del s področja primerjalne in medkulturne filozofije, ki se ukvarjajo z omenjenimi temami stare elementarne misli in filozofije narave v vedski Indiji in predsokratski Grčiji.

Ključne besede: vedska filozofija, predsokratiki, hrana, zrak, voda, ogenj, filozofija narave, primerjalna filozofija

\section{Introduction}

Within the ancient Vedic tradition, the elemental mystery of the world and the ontology of emanations of being and blossoming of life through the elements is in the forefront of its mytico-religious revelation. Thus air, water, food, earth and fire can be traced in their cosmic emanations through Vedic gods and mesocosmic "connections" (understood as bandhu and upanișad) (Upanișads 1996, lii-lvi). The main aim of this article is to compare these ancient elements from the Vedic period to the Presocratics: as already observed by Ranade in his Constructive Survey of Upanishadic Philosophy (1986), it is through the independent parallelism that we can compare Raikva's natural philosophy of vāyu/prāna with Anaximenes's pnêेmalaér teaching. Vedic teaching on water as brought to us in pañcāgnividya from Chāndogya Upanișad and Brhadäranyaka Upanișad will be brought into dialogue with Thales's natural philosophy of water; finally, teaching on fire as heat being present in all beings and the related cosmic teachings on fire will be compared to Heraclitus' natural philosophy of fire. Additionally, we will elaborate on the ancient Vedic element of "food" (anna), representing an idiosyncratic and archaic (and unique) contribution to elemental thinking.

As far as research by comparative philosophers is concerned, among the first to devote some attention to these two topics was Conger (1952). However, he only briefly examines Anaximenes, comparing his theory with the doctrines of the Upanișads, and fails to discuss Heraclitus' concept of fire in any detail. In his work on the history of Indian philosophy, Ruben mentions Anaximenes when analysing the Indian philosopher Uddālaka Āruni, whom he identifies as "the earliest of the materialists" (Ruben 1947, 81), chronologically locating him among the third generation of philosophers of the Upanișads, flourishing in the second half of the 7th century. But it is only with the work Early Greek 
Philosophy and the Orient by West (1971), which reserves ample space for extensive treatments of Anaximenes and, particularly, Heraclitus, that a broader insight into a series of possible direct and indirect links with the Upanișads, is enabled. Pajin, too, calls attention to the similarities between the teachings of Anaximenes and Raikva (Pajin 1980); and West's analytical work is completed with the markedly historicist approaches of Sedlar and Karttunen. ${ }^{1}$ Standing out among the students of Indian philosophy is the already mentioned $\mathrm{Ra}^{-}$ nade (1986), who in his chapter on the development of Upanișadic cosmology also touches on the link between Anaximenes and Raikva, a philosopher of the Upanișads (Chändogya Upanișad 4.3.1-4), and in his conclusion, amid numerous examples of analogies in the teachings of the two, upholds the importance of "independent parallelism" (Ranade 1986, 74) which allows comparison of cognate doctrines without constraining them into a framework of direct or indirect influences, historic contact, or even a common source (i.e., of Indo-Europeans), which are so extensively studied by West and Karttunen. Boland and Wessel (1993) finally asserted the close affinity between these teachings of ancient philosophers (Anaximenes in particular) and the Indian "wind-breath doctrine" (the so called Wind-Atem-Lehre ${ }^{2}$ ), while comparisons between Heraclitus and later Greek thinkers and Indian philosophers from Uddālaka Āruṇi onwards have been examined by Scharfstein (1998).

\section{Food as an Element in Ancient Indian Philosophy ${ }^{3}$}

Let us begin with an idiosyncratic example of an ancient teaching of the elemental world and its cosmico-natural significance. Within Western and Eastern traditions of mythological thinking and philosophy there are only few testimonies for the philosophical or even metaphysical relevance of food and eating. With few exceptions - such as Aristotle and Feuerbach—the philosophy or metaphysics of food and nutrition has been poorly represented in Western

$1 \quad$ Sedlar draws interesting parallels between regarding the role of wind/breath in Greek and Indian medicine (and mentions Anaximenes from the Greek pole of this learning); he ascribes to Heraclitus points of convergence with Buddhism, but also associates him with the Upanișadic doctrines of breath and fire (Sedlar 1980,17ff.). Karttunen rejects any (even indirect) link between Anaximenes and Heraclitus, on the one hand, and Indian doctrines, on the other, but he does mention some similarities between them (Karttunen 1989, 11ff.).

2 For this teaching we draw on Die Wind-Atem Lebre in den älteren Upanișaden (Boland 1997).

3 This part of our essay draws on an earlier encyclopaedic article titled "Food in Ancient Indian Philosophy” (Thompson and Kaplan 2014). Reprinted with permission. 
philosophical tradition. ${ }^{4}$ In contrast, the ancient Indian natural philosophy of the Vedas brings important mythico-philosophical testimonies on the cosmic food cycle, as well as early philosophical elaborations on the role of food. Moreover, it is only in the Vedas that an old mythico-philosophical theory of food as an element is presented in a cosmico-ontological key. Apart from their rich philosophical, ethical and comparative relevance for various philosophies or disciplines of the body (yoga, vegetarianism), ancient Vedic teachings on food and the food cycle can also substantially inform contemporary environmental philosophy and philosophy of religion (or philosophical theology).

For the Upanișadic philosophers there existed four or five originary elements of the world: earth, water, fire, air, and ether/space (see Praśna Upanișad 4.7: "[...] earth and the elements of earth; waters and the elements of water; fire and the elements of fire; wind and the elements of wind; space and the elements of space [...]" (Upanișads 1996, 284)). As such they are fully parallel to the five Greek elements as listed by the Presocratic philosophers (interestingly enough, in Feuerbach we have earth, water, light, air, and food; see Feuerbach 1989). But it is in the special role attributed to food that the natural philosophy of ancient Vedic India substantially diverges from the related Greek testimonies. Being aware of natural relations between "food" (anna) and "eater" (attr ), some Vedic philosophers included food among the originary elements and even attributed it a primary role among them. Here two interrelated doctrines appeared: about the water-cycle and about food. Of course, both food and eater are fundamental categories of biology: plants and animals produce food, or, rather, constitute the food for each other in the cycle of life. On the other hand, water is another originary source of life for early Vedic thinkers-such as rain, which falls on the ground and "feeds" plants, animals, and humans. Book XI of the Satapatha Brābmana presents the legendary story of Bhrgu, the son and pupil of the god Varuna. Being too proud and too confident, Bhrgu was sent to the jungle by his father. As Bhrgu looked in all four directions, he experienced horrible scenes of cannibalism, men dismembering men and eating their limbs. Upon his return to his father, Bhrgu receives Varuna's explanation: what he has witnessed were scenes from the world beyond, where men were representing the angry souls of plants, trees and the animals, all of them seeking retribution for being killed and eaten in their lives in this world. Bhrgu thus receives from Varuna a lesson about the interconnectedness of all living things: he learns that the whole universe is nothing but food (Śatapatha Brāhmana 11.6.1-135). But

4 Cf. here an excellent book on food and theology titled Food \& Faith (Wirzba 2011). On Feuerbach's teaching on food see Škof $(2015$, ch. 5). 
at the same moment, the story of Bhrgu is also an early example of a deeper sacrificial awareness - not yet about vegetarianism, but about the elemental meaning of food and a lesson about the deeper meaning of food sacrifice (Ruben 1947). Later, this will lead to a new ethical awareness, as exemplified in the teachings of Buddhism and Jainism, and the tradition of vegetarianism in Hinduism. Now, in Taittiriya Upanișad III there is another version of this legend. Here Bhṛgu learns the doctrine about brábman and food: according to Varuna, brábman is food, for it is from food that beings are born, on food they live, and to food they pass upon death. Given the Vedic meaning of brábman as a mysterious power of poetic formulation, or truth formulation (and later, in Vedānta, the absolute), and equating it with food, Bhrgu is finally instructed by Varuna to practice austerity.

In the early Upanișads food is recognized both as an originary material/empirical as well as spiritual/metaphysical substance: in Taittirìya Upanișad 2.2.1, a human being is formed from the essence of food:

From food, surely, are they born;

all creatures that live on Earth.

On food alone, once born, they live;

and into food in the end they pass.

For food is the foremost of beings,

so it is called 'all herbs'.

(Upaniṣads 1996, 185)

Similarly, in the earlier Brhadaranyaka Upanișad 1.5.1, food is worshiped as the highest of all, as brábman itself. The poetic verses read as follows:

By wisdom and by toil,

when the father produced

the seven kinds of food -

One was common to all here.

Two he assigned to the gods.

Three he kept for himself.

One he gave to the beasts. 


\begin{abstract}
All beings depend on it,
both those that breathe

and those that do not.
\end{abstract}

Why aren't they exhausted,

when they are eaten every day?

The man who knows it

as the inexhaustible -

he eats food with his face;

he reaches the gods;

he lives on invigorating food.

(Upaniṣads 1996, 18)

Here this pre-Buddhist Upanișad lists seven kinds of food, being created by the father of the gods, Prajāpati: among the various foods given to the creatures, milk is of the foremost importance (as explained in the commentary to the above verses in the Upaniṣad itself-see Brhadāranyaka Upanișad 1.5.2). Next, by following the Upanișadic teaching, and by the means of daily sacrifice, the sacrificer who knows this (in famous Upanișadic phrase "ya evam veda") and follows this ancient teaching-i.e. the sacrificer who firmly establishes himself/herself as a Person/ Creator-also knows the inexhaustible spiritual origin (food) of everything, and thus receives an inexhaustible amount of (material) food. ${ }^{6}$ So it is clearly stated in this passage how food serves both as a material and spiritual basis of everything. Food and liturgical acts (rituals, including various daily practices) are interdependent and have ethical consequences.

In the Brhadāranyaka Upanișad 1.2.1 we have a famous cosmogonic story about Death (Mrrtyu, m.) as the primeval deity: according to the Upanișadic philosophers Death is equated with hunger, and this thus indirectly indicates the key cosmologico-ontological role of food for the living. Moreover, Death emitted water,

6 See Bṛadãranyaka Upanișad 1.4.17: "Anyone who knows this obtains this whole world" (Upaniṣads 1996, 17); Sskt: tad idam sarvam äpnoti ya evam veda (Limaye and Vadekar 1958, 190). 
which then solidified into earth, and from the heat (tapas) emitted in this process fire was created. Air is also added to the elements. Mrtyu began to eat everything he created and thus he became the eater of this world, with the entire world being his food (Brhadäranyaka Upaniṣad 1.2.5: "He began to eat whatever he gave birth to," Upanișads 1996, 8). Finally, there is another important correlation, namely between food and breath (prāna). In the Brhadāranyaka Upaniṣad V, both "Brahman is food" and "Brahman is lifebreath" are uttered by the Upanișadic philosopher (Brhadāranyaka Upanișad 5.12.17). But food and breath (or air) are closely interdependent. In a story about Prātṛda and his father from the Brhadāranyaka Upanișad 5.12.1, Prātṛda is instructed about reaching pre-eminence as follows: all beings need food, and all beings likewise need (life) breath. This ancient Upanișadic teaching of the elements of food and air suggests the following: bodies subsist on a hidden cosmic, or empirico-metaphysical reserve of food and cosmic wind, or breath. The ancient "wind-breath-doctrine", as presented in the early Upanișads, strongly attests this (see Boland 1997). Finally, the whole universe is nothing but food; in his substance, man is now identical to the metaphysical food, or brábman, the first and ultimate creator and consumer of everything (Geib 1976, 225-28).

Another of the key early Upaniṣads, Chāndogya Upaniṣad 6.2.1-4, reveals a cosmogonical story closely related to food: in the beginning this world was One, without a second. In the process of becoming many, this primeval One first emitted heat, then water (as a result of cosmic perspiration), and finally from the rain it emitted food. Important teachings on the essence of food can be found also in Aitareya, Kaușitaki, and Mundaka Upanișads. Aitareya Upanișad 1.2.1 brings a cosmogonical story about hunger and thirst, which both affected the micro- and macrocosmic deities (i.e., cosmic realities) in the Upanișads, such as the human body and the cosmos. Immediately after they were created/emitted from the Self (ätman), they fell into the cosmic waters/ocean. From these waters, food was created for them by this Self:

Once these deities were created, they fell into this vast ocean here. It afflicted him with hunger and thirst. Those deities then said to him: 'Find us a dwelling in which we can establish ourselves and eat food'. (Upanișads 1996, 196)

To sum up: within the ancient Upanișadic teachings, food is frequently presented as the "the material substratum of all beings" (Geib 1976, 226), which is revealed in the seed from which all living things evolve. Taittiriya Upanișad describes how

7 Sskt: “annaṃ brahma [... ] prāno brahma” (Limaye and Vadekar 1958, 262). 
all beings evolve from food, live in it, and revert to it, ${ }^{8}$ and in this Upanișad the world, analogously to the passage from Brhadāranyaka Upanișad 1.4.6, is divided into two poles: the food (anna) and the eater (attr). Food is thus "pre-existing matter" and "empirical food consisting of beings eating each other", whereby all is "reduced to the one metaphysical substance" (ibid.).

\section{Ancient Indian Water Doctrine and Comparison with Thales's Philosophy}

The earliest Upanișads bear testimony to the beginnings of philosophical thinking comparable to the role of the Ionian philosophers, at least with regard to their philosophy of nature in ancient Greece. Schneider thus speaks of the "morphologically comparable phenomena of two high cultures" (Schneider 1961, 1). The question concerning both cultures is to what extent it is possible in this case to speak of a philosophy of nature. The definition adopted by Boland in her monograph about the wind-breath doctrine (Boland 1997) is centred on the following constituents of natural philosophy: the question of the principle (or the element of being: e.g. water in Thales); an observation method that breaks with the exclusively mythological discourse; the related knowledge; and, ultimately, the (philosophical) explanation of the whole of cosmic and human life (ibid., 8).

A presentation of this kind within ancient Indian philosophy was attempted by Frauwallner in his History of Indian Philosophy from 1953. In the framework of Upanișadic philosophy, Frauwallner was the first to systematically speak of three doctrines: the water doctrine, breath doctrine, and fire doctrine (Frauwallner 1953, 36-47). The doctrine of water as a lifegiving principle is based on insight gained by ancient philosophers of nature through observation: water in the form of rain nourishes plants, humans are sustained by mothers' milk, and at the time of a person's death, through the moisture carried into the sky by the smoke from the funeral pyre, water returns to its source and comes full circle. Ancient Indians claimed that water flows out of the Moon, which is constantly, as it were, "filing up" and "emptying out" according to its phases. It is an old Vedic belief that the Moon contains soma, the beverage bestowing immortality to the gods, and that the heavenly waters raining down on humans, feeding them, also originate in the Moon (ibid., 37-39). Now, Schneider argues that the doctrine about the circulation of water-from its origin in the Moon through rain to the plants and from

8 Sskt.: "annädvai prajāh prajāyante | yāh kāśva prthivīm śritāh |atho annenaiva jìvanti |athainadapiyantyanttatā |" (TU 2.2); "annāddhyeva khalvimāni bhrtāni jāyante | annena jätāni jìvanti | annam prayantyabhisamvisantìti|"(TU 3.1.2) (Limaye and Vadekar 1958, 55, 59). 
there through the food consumed by man, into the seed from which an embryo develops - is evidence of an already rational philosophical thought that does not require śäddha or faith to be understood (Schneider 1961, 4-5). This doctrine does reveal a clear tendency to search for that material first cause of the incessant emergence and passing away of the things that are in the world.

Do the food and water doctrines have any parallels in the Greek world of thought? Can water, the material cause or arche in Thale, ${ }^{9}$ also be conceived of as the (material) substratum/substance/essence (bypokeimenon) of being? Such an interpretation, as well as the terms "element" (stoicheion) and "substratum" (bypokeimenon), would already be in line with the ideas of Aristotle (and here we can note that it would be equally uncertain to apply Greek philosophical terms, of later origin, to Indian philosophers). In a section of Metaphysics (983b 6-10), Aristotle suggests an interesting explanation about the role of the principles of being, which is analogous to the passage of Taittiriya Upanișad 2.2: ". "..] that of which all things that are consist, and from which they first come to be, and into which they are finally resolved [...]" (Barnes 1995, 1556f). But can we say that Thales, too, understood the principles of being in this same way? Guthrie associates the term arché (which was also used by Aristotle) with its use in the meaning of "beginning" and "cause", which was already known during the period of the Ionian philosophers and, even before that, by Homer, remarking that the first to use the term arché was most probably Anaximander. If we apply this meaning now to water, we can say that "all things were once water [...], and to the philosopher all things are still water, [...] in spite of the changes" (Guthrie 1992, 57). Whereas the Vedic philosophers might have chosen water because of its biologically discernible role in the emergence and sustenance of all that is-acknowledging it through, as it were, a proto-rational-experimental analysis as the first principle or cause of being - what led Thales to it appears more difficult to determine. The idea that Thales might have been persuaded by the descriptions of the flooding of the Nile in Egypt and the related annual emergence of life-as Aristotle's report stating that for Thales the Earth floats on water (On the Heavens, 294a 28) seems to confirm—can also be found in Middle Eastern mythology (Guthrie 1992, 58-61). Even a rational explanation offers parallels with the Indian search for an explanation on this point, and according to Aristotle's conjecture the moisture-containing seed in Thales could refer to a connection with the origin of all life, and water is

9 Thales of Miletus ( $f .585$ BCE) may have been a Greek contemporary of Pravāhaṇa Jaivali.

10 Together with the Aitareya Upanișad and the Kausitaki Upanișad, the Taittirìya Upanișad forms the group of early prose Upanișads, which were probably created around the 6 th/5th century BCE, while the creation of the two most ancient Upanișads- the Brhadäranyaka and the Chandogyacan be dated as far back as the 7th/6th century BCE (Olivelle 1996, xxxvii). 
also associated with the vital heat that disappears at death when the body dries up (Metaphysics, 983a 20-28). Water or moisture (bygrós) is thus the original matter that might, in the early days of philosophy, have been considered the beginning of all life as "the continuing, hidden constituent of all things" (Guthrie 1992, 94). These doctrines from both pre-Buddhist India and Presocratic Greece indicate a new way of thinking and rationalizing the emergence, existence, and passing of living things, which culminate in the wind-breath and fire doctrines.

\section{Ancient Indian Wind-Breath Doctrine and Comparison with Anaximenes's Philosophy}

The former two doctrines bring us to the breath, or the so called wind-breath doctrine, which, as we shall see, opens up interesting comparative possibilities. The special importance of breathing can be traced back to the Vedic Samhitās. In the Rksambita, breath (pranna; from the root of the verb *an-in the sense of "to breathe"), which is associated with life, also represents a link with the cosmic wind or god of wind (vāyu) (Brereton and Jamison 2020, 94). In one of the major hymns of the Rksambita (10.90.13), we can identify a link between the cosmic wind (vajyu) and the breath of the first cosmic person (purusa):

The Moon was born from his mind. From his eye the Sun was born.

From his mouth Indra and Agni, from his breath Vāyu was born.

(The Rigreda 2014, 154011)

This connection and interdependence of microcosm and macrocosm already reveals one of the most characteristic traits of later Brahmanic and Upanișadic thought - the interpretation of reality through an analogy between a description according to the world of gods and according to the world of the self (i.e., adbidevatam and adbyātmam). Further, the same hymn also contains four of the later vital powers or "breaths" (prānăh, and thus in plural) as they will be then numbered in the earliest Upanișads. For example, in the Aitareya Upanișad 3.2-8 the group of five basic vital functions consists of breathing, sight, hearing, speech, and thinking (they are referred to in the idiosyncratic Vedic plural after the first of them-i.e., the breath). Moreover, in R Rsambita 10.189.2 we can also find the rudiments of a third type of reading of prāna or breath-namely, a fundamental connection with the process of breathing (this is the first and only example of

11 Sskt.: "candramā manaso jātaś cakṣoh ș̣ryo ajāyata | mukhād indraś cāgniśs ca prānād vāyur ajāyata ||" 
inhaling/exhaling, apāna/prāna that appears in the Rksambita), which later, as we shall see, manifests in the discussion about the five types of breath, particularly important in yoga and traditional Indian medicine (Zysk 1993,198ff.). The verses of this Vedic hymn read as follows:

This dappled cow has stridden here and sat in front of its mother

and its father, as it goes forth toward the Sun.

She moves within the realms of light, breathing in from his

breathing-out.

The buffalo has looked out across heaven.

(The Rigueda 2014, 1660).

Crucial to comparative philosophy are passages of the Upanișads associating breath with life and the self (atman). The earliest Upanișadic testimony of the wind-breath doctrine, originating from the Samhitā period, can be traced back to Jaiminìya Upanișad Brābmana 3.1-2 (which corresponds to the passage from Chāndogya Upanișad 4.1-3 in which we encounter the Upanișadic philosopher Raikva). ${ }^{12}$ In relation to the gods (adhidevatam), the Jaiminìya Upanișad Brāhmana 3.1.1-13 first describes how the wind is the only complete divinity, as all other divinities (devatāh), which here could be understood as "natural forces"these are the Sun, Moon, stars, fire, day, night, cardinal points, Parjanya, waters, herbs, and trees-revert back to it, while the wind is the only complete samman. It is important to highlight that wind holds such divine status due to its constant movement. And in relation to the self (adhyätmam; see Jaiminìya Upanișad Brāhmana 3.1.14-19), breath is the only samman into which the remaining four of the five vital powers, namely speech, thinking, sight and hearing-which are otherwise active in man together with breath-revert to during sleep. In the conclusion of Jaiminìya Upaniṣad Brāhmaṇa 3.2.1-4 we eventually witness kṣatriya Abhipratārin Kākṣaseni calling àtman the one who eats without being eaten (cf. the food doctrine!): this atman - here in the sense of breath-now refers both to gods and humans. Thus the macrocosmic wind is here linked to the breath in man. Since wind stood cosmically above breath already in the Rksambita (as vertically macrocosm is above the microcosm) and is also the one into which breath reverts at death, this doctrine is called by Boland (1997) the wind-breath doctrine. Related to these two passages is also a somewhat later teaching from the Brhadaranyaka Upanișad 1.5.21-23 about the competition among the five types of breath

12 Ruben (1947) classifies Raikva among the first generation philosophers of the Upanișads (700-670 BCE). 
$(\text { prāna } \bar{h})^{13}$ or vital/spiritual powers transferred to the wind and corresponding natural phenomena or divinities. Although the Jaiminiya Upanișad Brāhmana text as part of the Samaveda is primarily still in the service of mythological thinking, it already provides occasional "natural philosophical reflections" (Boland 1997, 39) as well.

The five breaths doctrine defines the next stage in the development of the doctrine of breath, which was in its rudimentary state present already in the Saṃitās and Brāhmanasas and started to appear in the Upanișads concurrently with the mentioned teachings of breath as vital power; but now we are not talking about the vital and cognitive powers, but rather the five types and processes of breathing or breath within humans. These now include präna, apāna, udāna, vyāna and samāna (Zysk 1993, 201). In relation to the role of each breath we should mention the treatment by Bodewitz $(1986,344)$, who proposes the following principal meanings for the mentioned breaths: exhalation (prāna) and inhalation (apāna; also digestive/abdominal breath, downward-moving and governing excretion) as the

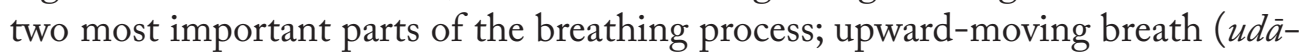
$n a$; also inhalation), breath between inhalation and exhalation (vyāna; air diffused throughout the body), and, finally linking breath (samāna; breath between prāna and apāna, which is, in contrast to vyāna, congested in the lower part of the body).

Moving now to the Greek parallels of this doctrine, it should be noted that in Greek philosophy prior to Plato no such development of the concept of breath as a life-giving principle that would lead towards a theory of breaths in the body can be observed. Still, Anaximenes provides some interesting parallels to the doctrine. Anaximenes's air (aér) as the first principle represents the pinnacle of wind-breath in the monistic philosophy of the Ionians. Guthrie (1992) points out that Anaximenes's choice of air for arché is more appropriate than Anaximander's apeiron. Anaximenes proceeds from the fundamental characteristic of the air, which subsists through rarefaction and condensing as the substratum of all being, whereas apeiron as the Boundless that enters the various things, thus is then in a way

13 Prāna in the sense of breath is in the plural (prānăh) a generic term denoting human bodily/vital faculties, the number of which ranges between five and twelve. The five "breaths" consist of the following five faculties: the breath (prāna $)$, the speech ( $v \bar{a} c)$, the sight (caksus), the hearing (śrotram), and the mind (manas) (see Kaușitaki Upanișad 1.7; the Śatapatha Brähmaṇa already knows from two to the thirteen prānas, as well as three types of breath; cf. Deussen 1915, 296ff.). These faculties can additionally include the senses of smell and taste, the body, the arms, the legs, the genital organs, and discernment (vijñana). This latter, besides breath, represents the most important aspect of the whole vital and cognitive essence of man (cf. Ježić 1999, 76ff.). In the Brhadäranyaka Upanișad 4.1 the five "breaths" are equalled to brábman and their base is in the heart. Typical of the development of the Upanișadic thought is that the breath doctrine gradually gives way to the doctrine of self (ätman), which also dwells in the heart. 
"no longer the Boundless", and the "differences of kind or quality are for the first time reduced to a common origin in differences of quantity" (Guthrie 1992, 116, 126). An even more important aspect of Anaximenes's philosophy-particularly in comparison with Indian teachings-provides the second reason for choosing air as the arché, namely its function as the carrier of life. Even in ancient Greece it is possible to encounter ancient images that connect breath, life, air and soul. Already in Homer man is invested with two forces or vehicles of life-thymós and psyché. Thymós or life force, comes into man out of cosmic energies and governs the emotional and mental processes in him/her. Its action is concentrated in the area of the chest (phrén) and heart (kér, kradie), which maintain these activities by constant movement. The principle that expresses man's thymós, and thereby their vitality, through breathing is psyche. With death, the link between the life force and the body is severed, and thymós joins again the flow of cosmic energies (Dietz 2000, 71-74). It is thus possible, even in periods preceding Anaximenes, to juxtapose the ancient Indian (already Rgvedic) conception of prāna as vital breath which at death re-enters cosmic wind, with the Greek (Homeric) thymós in the sense of a vital force which at death reunites with its cosmic origin.

This brings us to the well-known passage in which Aetius in his work Peri archon from the 1st/2nd century AD reports the following from Anaximenes: "As our soul, he says, being air holds us together and controls us, so does wind [or, breath] and air enclose the whole world" (Kirk, Raven and Schofield 1999, 158). ${ }^{14}$ In this sentence or, better, report about the teachings of Anaximenes, the cosmic aér is likened to pneuma in man. In comparison to Indian teaching-while the windbreath doctrine was included in the doctrine of the two "gatherers" (prāna and vāyu) into which all other vital faculties and cosmic phenomena revert-Anaximenes's teaching about the link between the human breath and the cosmic air can be interpreted as a typologically analogous expression of a universally present knowledge about the nature of human life and, more strictly, our soul (in the sense of the five Indian "breaths" or vital powers—as one whole of physical-spiritual faculties - and Anaximenes's teaching, which originates from an ancient Greek connection between breathing and the soul). Boland and Wessel (1993, 106f.), however, point out the asymmetry in terminology: in Anaximenes, aér is a joint term for the micro- and macrocosmic reality, while the Indian wind-breath doctrine does not understand the terms prāna and vāyu as synonyms. Further, the Indian doctrine does not speak about the rarefaction/condensing of air. But recalling that in the more ancient layers of the Indian wind-breath doctrine the transfer

14 Gr.: "hoîon he psyché, fesín, he hemetéra aér oûsa synkrateî hemâs, kaì hólon tén kósmon pneûma kaì aér periéchei” (Diels and Kranz 1934, 95 [fr. 13 B 2]). For more about the contextual meaning of this sentence see Alt 1973. 
to the macrocosm must have followed reflections about human beings, we should presume the same for Anaximenes. Or, as Barnes states:

We men contain an airy soul; and that air keeps us together, i.e., keeps us alive; the universe as a whole contains air: hence it is air that keeps the universe together, i.e., supplies its underlying stuff. (Barnes 1996, 55)

Although a "fully developed and clear-cut use of the inference from the known microcosm, man, to the unknown macrocosm, the world as a whole [...]" (Kirk, Raven and Schofield 1999,161) likely did not occur in Greece before the 5th century $\mathrm{BCE}$, we may still allow the possibility that the link, in one form or another, was drawn by Anaximenes, which is why its parallelism with the Indian doctrine is also comparatively interesting.

\section{Ancient Indian Fire Doctrine and Comparison with Heraclitus}

For Frauwallner, the fire doctrine is the most important of the three doctrines he examines (water, air and fire; see Frauwallner 1953, 45-49). It is based on the ancient observations of bodily warmth, in which the first Indian philosophers recognized the fire that dwells in all beings (agni vaisvannara). This divinity, which can already be found in the Rksambita, and whose very name bespeaks its roleof a fire belonging to all humanity-represents both the celestial and terrestrial fire (Macdonell 1995, 99). However, the fire dwelling in man, and of which the Upaniṣads speak (Bṛhadāranyaka Upaniṣad 5.9 and Chāndogya Upaniṣad 3.13.7 respectively), differs from its personified divine and mythological image as encountered in earlier texts. Its significance for the early Indian philosophy of nature lies in that its existence-and thereby the role of the physical substratum in the human body — can be demonstrated empirically as well: we can hear the fire roar/ hum when we cover our ears, and its power is revealed in that it digests the food we have consumed, thus giving us warmth, which can be felt by touching our skin (Frauwallner 1953, 45). The doctrine of fire is otherwise associated with the notions of connectedness between the micro- and macrocosm, which can be found already in the wind-breath doctrine. If water in the water doctrine comes from the Moon, then fire originates in the Sun, which at the same time represents the heavenly door through which this world receives heavenly light (jyotiș). The light that shines in the Sun is the same light that dwells in the human being (Chandogya Upanișad 3.13.7). The Sun is thus connected through its rays with the man into whom it flows and in whom the inner fire, by analogy, concentrates in the heart, from where it is then conveyed to the various parts of the body by the blood 
vessels. This circle (cf. the cycle of water and micro-macrocosmic analogies in the wind-breath doctrine) closes again at death, when the fire from man returns to his/her heavenly abode (Frauwallner 1953, 46). Already in the Rksambita Agni is the terrestrial fire that can consume everything else (Macdonell 1995, 89). The doctrine of the fire residing in man is also related to the notion of an eater who digests the food consumed by man and distributes the energy extracted from it throughout the body (Geib 1976, 229). Another important parallel between the wind-breath and fire doctrines can also be found in the sense of the Upanișadic doctrine of "gatherers" (samvargah) — for the roles of breath and wind in the cosmos have their counterpart roles in the fire in the body, on the one side, and the Sun in the cosmos, on the other (Chāndogya Upanișad 4.3.4). ${ }^{15}$

Finally, can the Indian doctrine of fire be compared to the role of fire in Heraclitus? In Heraclitus, fire is the original archetypal and eternal form of matter (cf. fr. B 30), which is the origin of thoughts (lógoi) about change and emergence of everything from antitheses (fire, sea/water and earth, and flame/lightning/prestér). The quantity of fire in this continual exchange or flow of change always remains the same: fire is, through this constant movement (starting and dying down according to métron and lógos), perpetually turning into non-fire, sea through evaporation into non-sea, earth through spillovers into non-earth. This movement, this constancy of change, testifies to a different substratum of thought than that encountered in Anaximenes, for change does not occur through some physical transformation (like condensing and rarefaction) of fire: "All things are an equal exchange for fire and fire for all things, as goods are for gold and gold for goods" (Kirk, Raven and Schofield 1999, 198). These words are evidence that Heraclitus deliberately did not choose an analogy to, say, Anaximenes's doctrine; instead, he emphasized with a merchant-like (originally non-philosophical and non-physical) comparison the meaning of the "parity of value: a certain quantity of gold will buy a certain quantity of goods" (Guthrie 1992, 461). Thus, rather than being the substratum or, as it were, a substance of all things, fire instead performs a special role from the viewpoint of passing into opposites; i.e., a process taking place in the world.

Regarding the question of comparative possibilities, West relies on an excerpt from Chandogya Upanișad 4.3. in which the doctrine of "gatherers" (samvargah) is described, specifically in the context of the wind-breath doctrine, which he himself associates with the exchange of elements in Heraclitus (fr. B 31), where, within the framework of the Upanișadic doctrine, fire is thus "consumed" by a cosmological "gatherer" or wind (West 1971,173f.). Although we may speak of two formally

15 "These, then, are the two gatherers- the wind among the deities and the breath among the vital functions (prāna)" (Upaniṣads 1996, 129). 
analogous methods, in the context of this doctrine fire does not play the same role as in Heraclitus. Therefore, it would appear more appropriate to compare fire in the perspective of its role as carrier of life: fire-which, as we have seen, is for Heraclitus an essential state of the soul-also "plays some part in the great cycle of natural change" (Kirk, Raven and Schofield 1999, 204). If we add that the dry (and therefore warm; i.e., dried as opposed to moist or wet) soul in Heraclitus is also associated with the heat of the Sun as the primary source of life (in fr. B 67a, the soul runs through the body like a spider across its web, while vital heat proceeding from the Sun gives life to all things that live) it is possible to draw a comparison with Indian thought or the doctrine of fire (Chāndogya Upanișad 3.13.7), where the light or heat connect the Sun and the human being, or the macrocosm and microcosm. Another interesting parallel between the Indian thought and that of Heraclitus is related to the role of breathing: in fr. A 16 it is conveyed through the words of Sextus Empiricus that in sleep "breathing is the only point of attachment to be preserved" (Kirk, Raven and Schofield 1999, 205). This introduces an interesting analogy with the doctrine of breath in the context of the five "breaths" or vital powers (prānāh), where, as we already know, prāna in the narrower sense is the only one among the vital/ spiritual powers to remain present even during sleep (Jaiminina Upanișad Brähmana 3.1.14-19). This parallel demonstrates how significant the phenomenon of breath/ ing and its constant active presence in the process of life is for the early Greek and Indian philosophies, despite its different role in both.

\section{Conclusion}

In his work about the comparative history of philosophy, Scharfstein sets Heraclitus within the social and philosophical frame of the beginnings of metaphysical philosophy—-together with the Upaniṣadic thinkers Uddālaka Āruṇi and Yājñavalkya on one side, and Parmenides on the other (Scharfstein 1998). But we have seen that it may be more appropriate to place Heraclitus in the context of the beginnings of Indian and Greek philosophy of nature and the doctrines of the first (material) principles. For intercultural philosophy the vital-cosmic breath, or air, appears to be one of the crucial phenomena for understanding the position of the human being in the world. Indian pre-Buddhist and Greek Presocratic philosophies throw a comparative and intercultural light on how the very idea of human embeddedness in the macrocosm has been present in the consciousness and early philosophical observation and analyses of these traditions from the very beginning: this early thought starts with the human body, making the latter the first phenomenon and object of understanding of an individual's involvement in and engagement with the surrounding world. 


\section{Acknowledgement}

This paper is a result of the ARRS research grant Surviving the Anthropocene through Inventing Nerw Ecological Justice and Biosocial Philosophical Literacy (J7-1824).

\section{References}

Alt, Karin. 1973. “Zum Satz des Anaximenes über die Seele.” Hermes 101 (2): 129-64.

Aristotle. 1995. "Metaphysics." In The Complete Works of Aristotle, vol. II, edited by Jonathan Barnes. Princeton, NJ: Princeton University Press.

Barnes, Jonathan. 1996. The Presocratic Philosophers. London: Routledge.

Bodewitz, Hendrik Wilhelm. 1986. "Prāṇa, Apāna and other Prāna-s in Vedic Literature.” Adyar Library Bulletin 50: 326-48.

Boland, Mechtilde, and Wessel, U. 1993. "Indische Spiritualität und griechischer Logos - Ein Gegensatz?" Jahrbuch für Religionswissenschaft und Theologie der Religionen 1: 90-117.

Boland, Mechtilde. 1997. Die Wind-Atem-Lehre in den älteren Upanișaden. Münster: Ugarit-Verlag.

Brereton, Joel P., and Stephanie W. Jamison. 2020. The Rigreda: A Guide. Oxford: Oxford University Press.

Conger, George P. 1952. “Did India Influence Early Greek Philosophy?” Philosophy East and West 2: 102-28.

Deussen, Paul. 1915. Allgemeine Geschichte der Philosophie mit besonderer Berücksichtigung der Religionen: Erster Band, Erste Abteilung: Allgemeine Einleitung und Philosophie des Veda bis auf die Upanișad's. Leipzig: F. A. Brockhaus.

—. 1938. Sechzig Upanișad's des Veda. Leipzig: F.A. Brockhaus.

Diels, Hermann, and Walter Kranz. 1934. Die Fragmente der Vorsokratiker, vol. 1. Berlin: Weidmannsche Buchhandlung.

Dietz, Günter. 2000. Menschenwürde bei Homer. Heidelberg: Universitätsverlag C. Winter.

Feuerbach, Ludwig. 1989. The Essence of Christianity. Translated by G. Eliot. Amherst, NY: Prometheus Books.

Frauwallner, Erich. 1953. Geschichte der indischen Philosophie, vol. 1. Salzburg: Otto Müller Verlag.

Geib, Ruprecht. 1976. "Food and Eater in Natual Philosophy of Early India." Journal of Oriental Institute 25: 223-35.

Guthrie, W. K. C. 1992. A History of Greek Philosophy. Cambridge: Cambridge University Press. 
Ježić, Mislav. 1999. Rgvedske Upanișadi. Zagreb: Matica Hrvatska.

Karttunen, Klaus. 1989. India in Early Greek Literature. Helsinki: Finnish Oriental Society.

Kirk, G. S., J. E. Raven, and M. Schofield. 1999. The Presocratic Philosophers. Cambridge: Cambridge University Press.

Limaye, V. P., and R. D. Vadekar, eds. 1958. Eighteen Principal Upanișads. Poona: Vaidika Samı́odhana Mạ̣dala.

Macdonell, A. A. 1995. Vedic Mythology. Delhi: Motilal Banarsidass.

Olivelle, Patrick. 1996. "Introduction.” In Upanisads, edited by Patrick Olivelle, xxiii-lvi. Oxford, New York: Oxford University Press.

Pajin, Dušan. 1980. Filozofija upanišada. Beograd: Nolit.

Ranade, Ramachandra Dattatrya. 1986. A Contructive Survey of Upanisadic Philosophy. Bombay: Bharatiya Vidya Bhavan.

Ruben, Walter. 1947. Die Philosophen der Upanișaden. Bern: A. Francke AG Verlag. Scharfstein, Ben-Ami. 1998. A Comparative History of World Philosophies. New York: SUNY Press.

Schneider, Ulrich. 1961. "Die altindische Lehre vom Kreislauf des Wassers." Saeculum 12: 1-11.

Sedlar,Jean.W.1980. India and the Greek World. New Jersey: Rowman \& Littlefield. Škof, Lenart. 2014. "Food in Ancient Indian Philosophy." In Encyclopedia of Food and Agricultural Ethics, edited by Paul. B. Thompson, and David M. Kaplan, 887-90. Dordrecht: Springer.

-----------. 2015. Breath of Proximity: Intersubjectivity, Ethics and Peace. Dordrecht: Springer.

The Rigveda: The Earliest Religious Poetry of India, vol. III. 2014. Translated by Stephanie W. Jamison, and Joel P. Brereton. Oxford, New York: Oxford University Press.

The Satapatha Brāhmana. 1994. Translated by Julius Eggeling. Delhi: Motilal Banarsidass.

Thompson, Paul. B., and David M. Kaplan, eds. 2014. Encyclopedia of Food and Agricultural Ethics. Dordrecht: Springer.

Upanisads. 1996. Translated by Patrick Olivelle. Oxford, New York: Oxford University Press.

Vlastos, Gregory. 1955. “On Heraclitus.” American Journal of Philology 76 (4): 337-68.

West, M. L. 1971. Early Greek Philosophy and the Orient. Oxford: Clarendon Press. Wirzba, Norman. 2011. Food E Faith. Cambridge: Cambridge University Press. Zysk, Kenneth G. 1993. "The Science of Respiration and the Doctrine of the Bodily Winds in Ancient India." Journal of the American Oriental Society 113: 198-213. 